\title{
PERANCANGAN METODE CERTAINTY FACTOR UNTUK DIAGNOSA GAGAL GINJAL KRONIS
}

\author{
Dede Abdurahman, S.Kom, MMSi ${ }^{1}$, Nunu Nurdianan, ST,. M.Kom² \\ ${ }^{1,2}$ Program Studi Teknik Informatika, Fakultas Teknik, UniversitasMajalengka \\ Email: ${ }^{1}$ dedeab@unma.ac.id, ${ }^{2}$ nun@unma.ac.id
}

\begin{abstract}
ABSTRAK
Penyakit ginjal adalah penyakit tidak menular dan saat ini menyerang sekitar jutaan orang di seluruh dunia. Satu dari sepuluh orang dewasa memiliki penyakit gagal ginjal kronis atau Chronic Kidney Disease (CKD). penyakit ginjal kronis di Indonesia sendiri pada tahun 2013 sebanyak 3.800 orang, kemudian meningkat tajam pada tahun 2018 menjadi satu juta orang. Data global di tahun 2019 menunjukkan, satu dari tiga orang umumnya berisiko mengalami penyakit ginjal kronis. Saat ini, 10\% dari penduduk dunia mengalami kondisi gagal ginjal kronis. Prevalensi penyakit ginjal kronis pada laki-laki $(0,3 \%)$ lebih tinggi dibandingkan dengan perempuan (0,2\%). Berdasarkan karakteristik umur prevalensi tertinggi pada kategori usia diatas 75 tahun (0,6\%), dimana mulai terjadi peningkatan pada usia 35 tahun ke atas. Penelitian Badan Penelitian dan Pengembangan Kesehatan (Balitbangkes) tahun 2004 menunjukkan konsumsi minuman bersoda dan berenergi lebih dari tiga kali perbulan berisiko 25,8 kali mengalami PGK. Bukti ilmiah menunjukkan bahwa komplikasi penyakit ginjal kronis, tidak bergantung pada etiologi, dapat dicegah atau dihambat jika dilakukan penanganan secara dini. Oleh karena itu, upaya yang harus dilaksanakan adalah diagnosis dini dan pencegahan yang efektif terhadap penyakit ginjal, dan hal ini dimungkinkan karena berbagai faktor risiko untuk penyakit ginjal dapat dikendalikan. untuk diagnosis dini penyakit ginjal dan dapat dilakukan semua orang, maka diperlukan suatu sistem pakar yang memudahkan masyarakat untuk mengaksesnya yaitu aplikasi sistem pakar. Sistem pakar untuk diagnosa penyakit Ginjal ini menggunakan metode runut maju (forward chaining) untuk menelusuri gejala yang ditampilkan dalam bentuk pertanyaan-pertanyaan agar dapat mendiagnosa jenis penyakit ginjal. Dalam penentuan penyakit dan pendiagnosaan diperlukan nilai kepercayaan terhadap gejala penyakit tersebut. untuk mendapatkan nilai kepercayaan terhadap gejala penyakit yang diderita, diperlukan suatu metode yang dikenal dengan Certainty Factor (CF).

Kata Kunci: Penyakit ginjal Kronis, sistem pakar Certanty Factor, Metode forward chaining.
\end{abstract}

\section{PENDAHULUAN}

\subsection{Latar Belakang}

Dunia kesehatan pada saat ini baik di Negara maju maupun Negara sedang berkembang tengah mengalami penyakit kronis tidak menular (cronic non-communicable diseases) terutama penyakit kardiovaskuler, hipertensi, diabetes melitus dan penyakit ginjal kronis, sudah menggantikan penyakit menular (communicable diseases) sebagai masalah kesehatan masyarakat di dunia. Salah satu penyakit tidak menular adalah adanya gangguan fungsi ginjal yang dapat menggambarkan kondisi sistem vaskuler sehingga dapat membantu upaya pencegahan penyakit lebih dini sebelum pasien mengalami komplikasi yang lebih parah seperti stroke, penyakit jantung koroner, gagal ginjal, dan penyakit pembuluh darah perifer. Pada penyakit ginjal kronis terjadi penurunan fungsi ginjal yang memerlukan terapi pengganti yang membutuhkan biaya yang mahal. Penyakit ginjal kronis biasanya desertai berbagai komplikasi seperti penyakit kardiovaskuler, penyakit saluran napas, penyakit saluran cerna, kelainan di tulang dan otot serta anemia. (Efrida Warganegara, 2016)

Pengelolaan penyakit ginjal kronis lebih mengutamakan diagnosis dan pengobatan terhadap penyakit ginjal spesifik yang merupakan penyebab penyakit ginjal kronis serta dialisis atau transplantasi ginjal jika sudah terjadi gagal ginjal. Bukti ilmiah menunjukkan bahwa komplikasi penyakit ginjal kronis, tidak bergantung pada etiologi, dapat dicegah atau dihambat jika dilakukan penanganan secara dini. Oleh karena itu, upaya yang harus dilaksanakan adalah diagnosis dini dan pencegahan yang efektif terhadap penyakit ginjal kronis, dan hal ini dimungkinkan karena berbagai faktor risiko untuk penyakit ginjal kronis dapat dikendalikan. (Tjekyan, 2012)

Penyakit ginjal sendiri diketahui selalu meningkat dari tahun ke tahun. Di Indonesia sendiri penyakit ginjal kronis pada tahun 2013 sebanyak 3.800 orang, kemudian meningkat tajam pada tahun 2018 menjadi satu juta orang. Data global di tahun 2019 menunjukkan, satu dari tiga orang umumnya berisiko mengalami penyakit ginjal kronis. Saat ini, $10 \%$ dari penduduk dunia mengalami kondisi gagal ginjal kronis. Namun sembilan dari sepuluh orang tersebut tidak menyadari kondisinya. Lebih dari 2 juta penduduk di dunia mendapatkan perawatan dengan dialisis atau transplantasi ginjal dan hanya sekitar $10 \%$ yang benar-benar mengalami perawatan tersebut. Sepuluh persen penduduk di dunia mengalami Penyakit Ginjal Kronis dan jutaan meninggal setiap tahun karena tidak mempunyai akses untuk pengobatan. Prevalensi gagal ginjal 
pada laki-laki $(0,3 \%)$ lebih tinggi dibandingkan dengan perempuan $(0,2 \%)$. Berdasarkan karakteristik umur prevalensi tertinggi pada kategori usia diatas 75 tahun $(0,6 \%)$, dimana mulai terjadi peningkatan pada usia 35 tahun ke atas. Penelitian Badan Penelitian dan Pengembangan Kesehatan (Balitbangkes) tahun 2004 menunjukkan konsumsi minuman bersoda dan berenergi lebih dari tiga kali perbulan berisiko 25,8 kali mengalami PGK (Penyakit Ginjal Kronis). (Kesehatan, 2017)

Penyakit ginjal kronis dapat dikenali secara dini, maka pengobatan dapat segera dimulai, dengan demikian komplikasi akibat penyakit ini dapat dicegah. Demikian pula pengenalan dan pengobatan hipertensi dan diabetes melitus secara awal serta berkesinambungan dapat mencegah penyakit ginjal kronis Pemeriksaan fungsi ginjal penting dilakukan untuk mengidentifikasi adanya penyakit ginjal sedini mungkin agar penatalaksanaan yang efektif dapat diberikan untuk mengetahui penurunan fungsi ginjal sejak dini dapat dilakukan dengan pemeriksaan darah dan urin : pemeriksaan darah dengan melihat kadar kreatinin, ureum, Laju Filtrasi Glomerulus (LFG), pemeriksaan urin dengan melihat kadar albumin atau protein. Pengukuran fungsi ginjal terbaik adalah dengan mengukur Laju Filtrasi Glomerulus (LFG). Melihat nilai laju filtrasi glomerulus (LFG) baik secara langsung atau melalui perhitungan berdasarkan nilai pengukuran kreatinin, jenis kelamin dan umur seseorang. Pengukuran LFG tidak dapat dilakukan secara langsung, tetapi hasil estimasinya dapat dinilai melalui bersihan ginjal dari suatu penanda filtrasi. Salah satu penanda tersebut yang sering digunakan dalam praktik klinis adalah kreatinin serum. (Iri Kuswadi, 2020)

Berdasarkan latar belakang diatas, untuk mendiagnosa sedini mungkin penyakit ginjal diperlukan suatu sistem pakar yang memudahkan masyarakat untuk deteksi sedini mungkin yaitu aplikasi sistem pakar. Sistem pakar untuk diagnosa penyakit Ginjal ini menggunakan metode runut maju (forward chaining) untuk menelusuri gejala yang ditampilkan dalam bentuk pertanyaan-pertanyaan agar dapat mendiagnosa jenis penyakit Gagal Ginjal. Dalam penentuan penyakit dan pendiagnosaan diperlukan nilai kepercayaan terhadap penyakit tersebut, untuk mendapatkan nilai kepercayaan terhadap penyakit yang diderita, diperlukan suatu metode yang dikenal dengan Certainty Factor (CF).

\subsection{Tinjuan Pustaka}

Sistem pakar (expert system) merupakan paket perangkat lunak atau paket program komputer yang ditujukan sebagai penyedia nasehat dan sarana bantu dalam memecahkan masalah di bidangbidang spesialisasi tertentu seperti sains, perekayasaan, matematika, kedokteran, pendidikan dan sebagainya. Expert system merupakan subset dari Artificial Intelegence. Keunggulan sistem pakar.

Sistem pakar adalah program komputer yang menirukan penalaran seorang pakar dengan keahlian pada suatu wilayah pengetahuan tertentu. Sistem pakar merupakan program "artificial inteligence" ("kecerdasan buatan" atau AI) yang menggabungkan basis pengetahuan dengan mesin inferensi. Ini merupakan bagian perangkat lunak spesialisasi tingkat tinggi atau bahasa pemrograman tingkat tinggi (High Level Language), yang berusaha menduplikasi fungsi seorang pakar dalam satu bidang keahlian tertentu. (Desaini, 2005)

Sistem pakar pertama kali dikembangkan oleh komunitas AI pada pertengahan tahun 1960. Sistem pakar yang muncul pertama kali adalah General Purpose Problem Solver (GPS) yang dikembangkan oleh Newel \& Simon. Sampai saat ini sudah banyak sistem pakar yang dibuat, seperti MYCIN, DENDRAL, XCON \& XSEL, SOPHIE, Prospector, FOLIO, DELTA, dan sebagainya.

Teori Certainty Factor (CF) diusulkan oleh Shortliffe dan Buchanan pada tahun 1975 untuk mengakomadasi ketidakpastian pemikiran (inexact reasoning) seorang pakar. Seorang pakar (misalnya dokter) sering kali tidak pasti dalam menganalisa suatu informasi yang ada dengan cara mengungkapkan mungkin, kemungkinan besar, hampir pasti. untuk mengakomodasi hal tersebut maka menggunakan Certainty Factor guna menggambarkan tingkat keyakinan pakar terhadap masalah yang sedang dihadapi. (Azhar, 2014)

Faktor kepastian (Certainty Factor) menyatakan kepercayaan dalam sebuah kejadian (atau fakta atau hipotesis) berdasarkan bukti atau penilaian pakar. Certainty factor menggunakan suatu nilai untuk mengasumsi derajat keyakinan seorang pakar terhadap suatu data.

Dalam perhitungan Certainty Factor dapat beberapa antensenden (dalam rule yang berbeda) dengan satu konsekuen yang sama, dengan menghitung nilai $\mathrm{CF}$ keseluruhan dari setiap kondisi yang ada. pada konsep Certainty Factor ini juga sering dikenal dengan adanya believe dan disbelieve. believe merupakan keyakinan, sedangkan disbelive merupakan ketidakyakinan. Menurut Sutojo, dkk 2011. Ada dua model yang sering digunakan dalam menghitung tingkat keyakinan (Certainty Factor) dari sebuah rule, sebagai berikut:

Metode "Net Belie" yang diusulkan oleh E.H. shortliffe dan B.G. Buchaman. (Riadi, 2017) 
$\mathrm{CF}($ Rule $)=\mathrm{MB}(\mathrm{H}, \mathrm{E})-\mathrm{MD}(\mathrm{H}, \mathrm{E})$ (1)

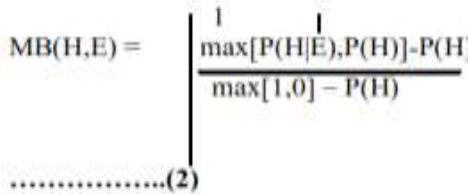

$\mathrm{MD}(\mathrm{H}, \mathrm{E})=\left.\right|^{\mathrm{I}} \frac{\mathrm{min}[\mathrm{P}(\mathrm{H} \mid \mathrm{E}), \mathrm{P}(\mathrm{H})]-\mathrm{P}(\mathrm{H})}{\min [1,0]-\mathrm{P}(\mathrm{H})}$

if $\mathrm{P}(\mathrm{H})=0$

Gambar 1

Dimana :

$\begin{aligned} \mathrm{CF} \text { Rule }(\mathrm{H}, \mathrm{E})= & \text { Faktor kepastian } \\ \mathrm{MB}(\mathrm{H}, \mathrm{E})= & \text { Measure of disbelief (ukuran } \\ & \text { kepercayaan) } \quad \text { terhadap } \\ & \text { hipotesis } \mathrm{H}, \text { jika diberikan } \\ & \text { evidence } \mathrm{E}(\text { antara } 0 \text { dan } 1) \\ = & \text { Measure of disbelief (ukuran } \\ & \text { ketidak percayaan) terhadap } \\ & \text { hipotesis } \mathrm{H}, \text { jika diberikan } \\ & \text { evidence } \mathrm{E}(\text { antara } 0 \text { dan } 1) . \\ = & \text { Probabilitas kebenaran } \\ & \text { hipotesis } \mathrm{H} \\ = & \text { Peristiwa atau fakta } \\ & \text { (Evidence) } \\ & \text { bahwa } \mathrm{H} \text { benar karena fakta } \mathrm{E}\end{aligned}$

Tabel 1. Bobot Nilai

\begin{tabular}{|c|l|c|}
\hline KODE & KET & NILAI \\
\hline SY & Sangat Yakin & 1 \\
\hline $\mathrm{y}$ & Yakin & 0.8 \\
\hline CY & Cukup Yakin & 0.6 \\
\hline SY & Sedikit Yakin & 0.4 \\
\hline TY & Tidak Tahu & 0.2 \\
\hline TY & Tidak & 0 \\
\hline
\end{tabular}

Menurut B.Wilson dalam (Kusrini, 2006), runut maju berarti menggunakan himpunan aturan kondisi-aksi. Dalam metode ini, data digunakan untuk menentukan aturan mana yang akan dijalankan. Proses diulang sampai ditemukan suatu hasil. Jadi dimulai dari premis-premis atau informasi masukan (if) dahulu kemudian menuju konklusi atau derived information (then) atau dapat dimodelkan sebagai berikut : IF (informasi masukan) THEN (konklusi). Informasi masukan dapat berupa data, bukti, temuan, atau pengamatan.Sedangkan konklusi dapat berupa tujuan, hipotesa, penjelasan, atau diagnosis. Sehingga jalannya penalaran runut maju dapat dimulai dari data menuju tujuan, dari temuan menuju penjelasan atau dari pengamatan menuju diagnosa. (Sestri novia rizki, 2017)

Berikut ini adalah daftar aturannya :

Aturan 1:

Jika premis 1

Dan premis 2
Dan premis 3

Maka konklusi 1

Aturan 2:

Jika premis 1

Dan premis 3

Dan premis 4

Maka konklusi 2

\subsection{Metodologi Penelitian}

Pada Penelitian Internal Universitas Majalengka ini peneliti membuat 3 tahap penelitian, diantaranya :

a. Tahap Pengumpulan Data.

a). kajian literasi terhadap jurnal jurnal yang berkaitan dengan penyakit ginjal dan metode Certainty Factor.

b). Melakukan observasi dan wawancara kepada pasien cuci darah yang berkaitan dengan gejala gejala penyakit ginjal kronis dan Pakar( Dokter KGH).

c). Analisa Sistem Pakar menggunakan Metode Certanty Factor.

b. Lokasi Penelitan.

Penelitian ini akan dilaksanakan di Dinas Kesehatan (Puskesmas) dan RSUD Majalengka serta Komunitas Pasien Cuci Darah Unit Majalengka.

c. Alur Penelitian

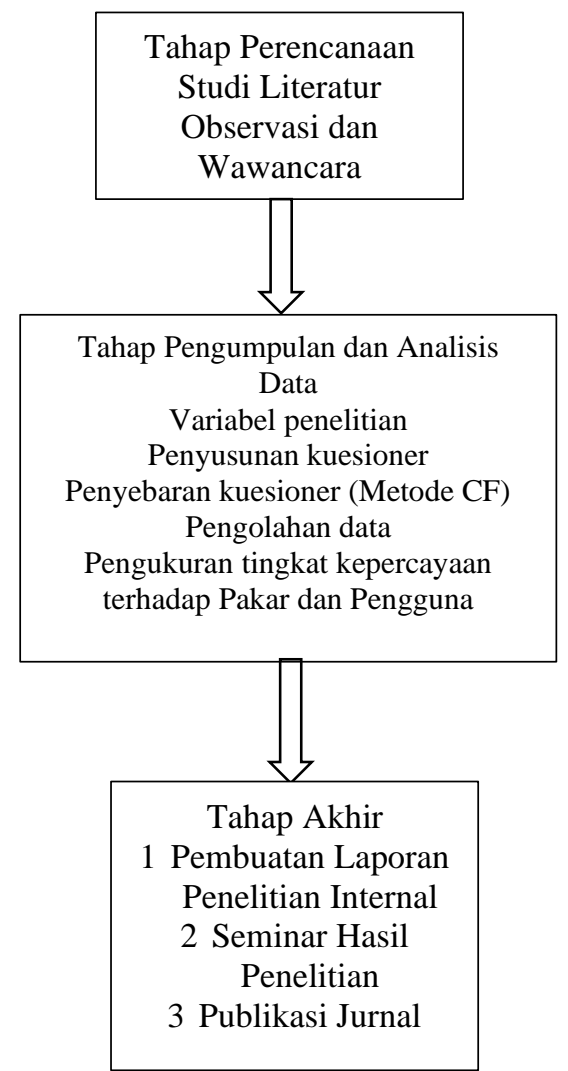

Gambar 2 Alur Penelitian 


\section{PEMBAHASAN}

\subsection{Analisa Metode Certainty Factor.}

Adapun analisa metode certainty factor pada sistem pakar ini adalah metode yang mengukur nilai kepastian yang diberikan oleh pakar terhadap suatu aturan dan mengatasi kesulitan dalam menentukan gejala-gejala terhadap Penyakit Ginjal Kronis.

Berikut ini adalah rumus Certainty Factor untuk mengansumsikan kepastian seorang pakar terhadap suatu data.

$\mathrm{CF}[\mathrm{H}, \mathrm{E}]=\mathrm{CF}[\mathrm{H}] * \mathrm{CF}[\mathrm{E}]$

CFcombine $\mathrm{CF}[\mathrm{H}, \mathrm{E}] 1,2=\mathrm{CF}[\mathrm{H}, \mathrm{E}] 1+\mathrm{CF}[\mathrm{H}, \mathrm{E}] 2 *$ $(1 \mathrm{CF}[\mathrm{H}, \mathrm{E}] 1)$

$\mathrm{CF}$ combineCF[H,E]old3 $=\mathrm{CF}[\mathrm{H}, \mathrm{E}]$ old $+\mathrm{CF}[\mathrm{H}, \mathrm{E}] 3$ * (1CF[H,E]old $)$

$\mathrm{CF}=$ Certainty Factor (Faktor Kepastian) dalam hipotesa $\mathrm{H}$ yang dipengaruhi oleh Fakta $\mathrm{E}$.

$\mathrm{E}=$ Evidence (Peristiwa atau Fakta)

Sistem Pakar Certainty Factor pada sesi wawancara dengan pakar dan pengguna diberi beberapa pilihan yang masing-masing memiliki beberapa bobot nilai sebagai berikut:

Tabel 2. Bobot Nilai

\begin{tabular}{|c|l|c|}
\hline KODE & KET & NILAI \\
\hline SY & Sangat Yakin & 1 \\
\hline y & Yakin & 0.8 \\
\hline CY & Cukup Yakin & 0.6 \\
\hline SY & Sedikit Yakin & 0.4 \\
\hline TT & Tidak Tahu & 0.2 \\
\hline T & Tidak & 0 \\
\hline
\end{tabular}

Dibawah ini adalah tabel hasil pembobotan wawancara dengan Pakar berdasarkan gejala gejala pada Penyakit Ginjal.

Tabel 3. Hipotesa Gejala berdasarkan CF Pakar

\begin{tabular}{|c|c|l|c|}
\hline No & Kode & \multicolumn{1}{|c|}{ Gejala Penyakit } & $\begin{array}{c}\text { Nilai } \\
\text { Hipotesa }\end{array}$ \\
\hline 1 & A1 & Mual & 0,8 \\
\hline 2 & A2 & Muntah & 0,6 \\
\hline 3 & A3 & $\begin{array}{l}\text { Kehilangan selera } \\
\text { makan }\end{array}$ & 0,4 \\
\hline 4 & A4 & $\begin{array}{l}\text { Mengalamai Kelelahan } \\
\text { dan kelemahan }\end{array}$ & 0,4 \\
\hline 5 & A5 & $\begin{array}{l}\text { Mengalami Masalah } \\
\text { tidur }\end{array}$ & 0,4 \\
\hline 6 & A6 & Tremor Pada Tangan & 0,6 \\
\hline 7 & A7 & $\begin{array}{l}\text { Pembengkakan pada } \\
\text { kaki dan pergelangan } \\
\text { kaki }\end{array}$ & 0,4 \\
\hline 8 & A8 & $\begin{array}{l}\text { Rasa gatal yang terus } \\
\text { menerus }\end{array}$ & 0,4 \\
\hline 9 & A9 & $\begin{array}{l}\text { Sesak Napas jika cairan } \\
\text { menumpuk di paru paru. }\end{array}$ & 0,4 \\
\hline 10 & A10 & Sakit Perut & 0,4 \\
\hline 11 & A11 & $\begin{array}{l}\text { Ketajaman mental } \\
\text { menurun }\end{array}$ & 0,6 \\
\hline
\end{tabular}

\begin{tabular}{|c|c|l|c|}
\hline No & Kode & \multicolumn{1}{|c|}{ Gejala Penyakit } & $\begin{array}{c}\text { Nilai } \\
\text { Hipotesa }\end{array}$ \\
\hline 12 & A12 & Otot berkendut dan kram & 0,4 \\
\hline 13 & A13 & Jarang buang air kencing & 0,4 \\
\hline 14 & A14 & Pucat & 0,4 \\
\hline 15 & A15 & $\begin{array}{l}\text { Sakit pada pundak dan } \\
\text { pinggang }\end{array}$ & 0,4 \\
\hline
\end{tabular}

Data Penyakit Ginjal hasil Wawancara di Objek Penelitian.

Tabel 3 di bawah ini menjelaskan mengenai 2 buah penyakit Ginjal beserta penjelasan dan upaya penangannya yang diperoleh dari hasil kajian literasi dari beberapa jurnal tentang penyakit ginjal dan e-book dari Perhimpunan Nefrologi Indonesia dengan judul "From Textbook To Digital Medicine Era" direkomendasikan langsung oleh dr. Iri Kuswadi, Sp.PD-KGH, dkk. Pada dasarnya, PGK (Penyakit Ginjal Kronis) terbagi ke dalam tahapantahapan, dimulai dari tahap berisiko, inisiasi (ditandai adanya albuminuria), progresi (ditandai adanya penurunan laju filtrasi glomerulus atau LFG), hingga akhirnya mencapai gagal ginjal. Tahapan-tahapan tersebut yang menjadi patokan dalam pencegahan PGK. Secara umum, pencegahan PGK dapat dibagi menjadi dua, yaitu prevensi primer dan sekunder. Prevensi primer adalah pencegahan sebelum terjadi PGK pada orang-orang yang berisiko (seperti diabetes melitus dan hipertensi), sementara prevensi sekunder adalah pencegahan PGK yang telah ada untuk menjadi semakin memburuk atau berkomplikasi. Prevensi primer PGK dilakukan pada tahap berisiko (sebelum terjadi PGK) dan prevensi sekunder PGK dilakukan pada tahap inisiasi (sebelum terjadi penurunan LFG). Prevensi, baik primer maupun sekunder, sangat penting peranannya pada tata laksana PGK.

Tabel 4. Data Penyakit Ginjal Berdasarkan CF Pakar

\begin{tabular}{|c|c|l|c|}
\hline No & Kode & \multicolumn{1}{|c|}{ Gejala Penyakit } & Kepercayaan \\
\hline 1 & P1 & Penyakit Ginjal Akut & 0,6 \\
\hline 2 & P2 & $\begin{array}{l}\text { Penyakit Ginjal } \\
\text { Kronis }\end{array}$ & 0,8 \\
\hline
\end{tabular}

Tabel 5.

Tabel 6. Basis Pengetahuan Penyakit Ginjal

\begin{tabular}{|l|l|l|l|}
\hline kode & $\begin{array}{l}\text { Nama } \\
\text { Penyakit } \\
\text { Ginjal }\end{array}$ & Definisi PGK & Pengobatan PGK \\
\hline P01 & $\begin{array}{l}\text { Penyakit } \\
\text { Ginjal } \\
\text { Akut }\end{array}$ & $\begin{array}{l}\text { yaitu tidak } \\
\text { berfungsinya } \\
\text { ginjal secara } \\
\text { mendadak yang } \\
\text { membuat ginjal } \\
\text { kehilangan } \\
\text { kemampuan } \\
\text { dalam menjaga } \\
\text { homeostatis } \\
\text { tubuh. Gagal } \\
\text { ginjal aknat andatan gagal } \\
\text { ginjal akut } \\
\text { bertujuan untuk } \\
\text { mencegah } \\
\text { komplikasi dan } \\
\text { mengembalikan } \\
\text { fungsi ginjal. } \\
\text { Pasien biasanya } \\
\text { perlu menjalani } \\
\text { rawat inap yang } \\
\text { lamanya }\end{array}$ \\
\hline
\end{tabular}




\begin{tabular}{|c|c|c|c|}
\hline kode & $\begin{array}{l}\text { Nama } \\
\text { Penyakit } \\
\text { Ginjal }\end{array}$ & Definisi PGK & Pengobatan PGK \\
\hline & & \begin{tabular}{l}
\multicolumn{2}{l}{ membuat } \\
kemampuan \\
ginjal untuk \\
mengalirkan \\
darah ke ginjal \\
menjadi \\
terhambat dan \\
terjadi trauma \\
pada ginjal. \\
Penyebabnya, \\
terjadi \\
peningkatan \\
kadar BUN dan \\
kretainin plasma.
\end{tabular} & $\begin{array}{l}\text { tergantung pada } \\
\text { seberapa parah } \\
\text { kondisinya dan } \\
\text { seberapa cepat } \\
\text { ginjalnya dapat } \\
\text { kembali pulih. } \\
\text { Metode } \\
\text { pengobatan gagal } \\
\text { ginjal akut } \\
\text { tergantung pada } \\
\text { penyebabnya. } \\
\text { Beberapa metode } \\
\text { pengobatan yang } \\
\text { bisa diberikan oleh } \\
\text { dokter adalah: } \\
\text { Pengaturan pola } \\
\text { makan, yaitu } \\
\text { dengan membatasi } \\
\text { konsumsi makanan } \\
\text { tinggi garam dan } \\
\text { kalium selama } \\
\text { proses } \\
\text { penyembuhan } \\
\text { ginjal } \\
\text { Pemberian obat- } \\
\text { obatan, yaitu } \\
\text { dengan } \\
\text { memberikan obat } \\
\text { yang dapat } \\
\text { menyeimbangkan } \\
\text { kadar elektrolit di } \\
\text { dalam darah, } \\
\text { memberikan obat } \\
\text { diuretik untuk } \\
\text { mengeluarkan } \\
\text { kelebihan cairan, } \\
\text { antibiotik jika } \\
\text { gagal ginjal } \\
\text { disebabkan oleh } \\
\text { infeksi bakteri. }\end{array}$ \\
\hline P02 & $\begin{array}{l}\text { Penyakit } \\
\text { Ginjal } \\
\text { Kronis }\end{array}$ & 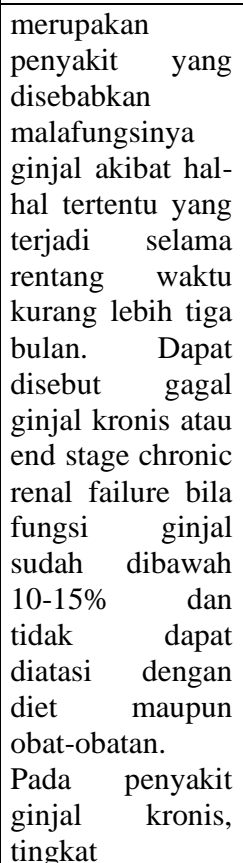 & $\begin{array}{llr}\text { yang } & \text { dapat } \\
\text { dilakukan, } & \text { yaitu } \\
\text { renal replacement } & \text { therapy atau tetapi } \\
\text { pengganti } & \text { ginjal. } \\
\text { Terapi ini } & \text { bisa } \\
\text { dilakukan } & \text { dengan } \\
\text { metode } & \text { dialisis } \\
\text { atau } & \text { metode } \\
\text { transplantasi } & \\
\text { (cangkok) ginjal. } \\
\text { Metode dyalisis } \\
\text { sendiri ada dua, } \\
\text { yaitu metode cuci } \\
\text { darah } & \\
\text { (hemodialysis) dan } \\
\text { metode cucu perut } \\
\text { (peritoneal } \\
\text { dialysis). }\end{array}$ \\
\hline
\end{tabular}

\begin{tabular}{|c|c|c|c|}
\hline kode & $\begin{array}{l}\text { Nama } \\
\text { Penyakit } \\
\text { Ginjal } \\
\end{array}$ & Definisi PGK & Pengobatan PGK \\
\hline & & \begin{tabular}{lr}
\multicolumn{2}{l}{ kemampuan } \\
ginjal dalam \\
menjalankan \\
fungsi-fungsinya \\
untuk menyaring \\
zat-zat risa \\
metabolism dari \\
tubuh sudah \\
tidak dapat \\
berfungsi \\
normal lagi \\
atau \\
dikatakan dalam \\
tingkat rang \\
parah.
\end{tabular} & \\
\hline
\end{tabular}

\subsection{Perancangan Sistem Pakar pada PGK}

Pada gambar 2 dibawah ini akan menunjukkan langkah dalam perhitungan sistem pakar Certainty Factor, yang pertama kali dilakukan adalah menghitung nilai $\mathrm{CF}$ (E) berdasarkan data gejala, dengan mengurangi Measure of Belief (MB) dan Measure of Disbelief (MD) yang merupakan nilai intrepetasi pakar terhadap suatu gejala terhadap suatu penyakit. Setelah mengitung nilai $\mathrm{CF}$ (E), selanjutnya dilakukan perhitungan dengan menggunakan rumus $\mathrm{CF}$ kombinasi untuk mendapatkan nilai setiap aturan.

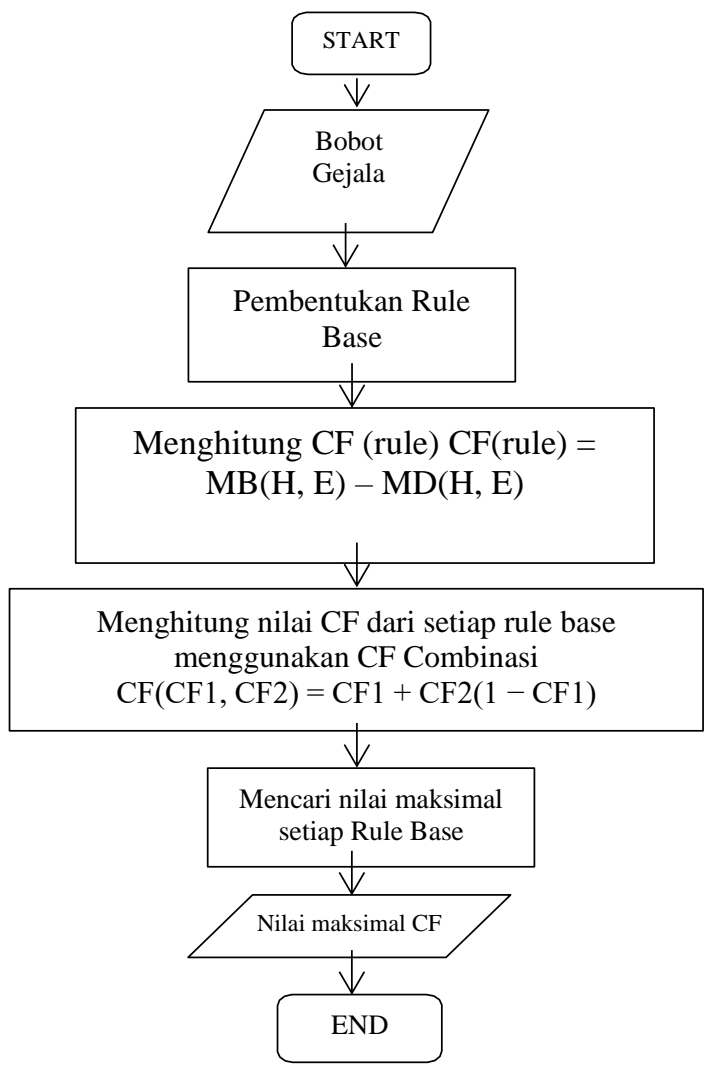

Gambar 2. Flowchart penelusuran Sistem Pakar Certainty Factor 
Pada gambar 3 dibawah menunjukkan detail mengenai flowchart sistem pakar diagnosa penyakit ginjal kronis adalah sebagai berikut.

a). Start menandakan program dimulai.

b). Setelah program dimulai maka akan ditampilkan data gejala penyakit.

c). User memilih gejala yang dirasakan.

d). Gejala yang telah diinputkan user akan dilakukan proses pembentukan rule base, dimana rule base berguna untuk mencocokkan data gejala dengan data penyakit.

e). Apabila tidak ditemukan gejala yang sama dengan data penyakit atau hanya ditemukan 1 data penyakit, maka proses tidak dapat dilanjutkan ke proses perhitungan. Namun jika ditemukan gejala yang sama lebih dari satu, maka proses akan berlanjut ke proses perhitungan sistem.

f). Sistem akan melakukan peritungan nilai $\mathrm{CF}$ secara keseluruhan dari gejala yang ada apa rule base.

g). Dari hasil perhitungan nilai CF dari masingmasing penyakit, maka akan dipilih nilai $\mathrm{CF}$ yang terbesar. Dimana nilai maksimal tersebut merupakan hasil dari diagnosa penyakit menurut gejala yang diinputkan user/pengguna.

h). Saat hasil akhir dari perhitungan CF selesai maka program akan berhenti.

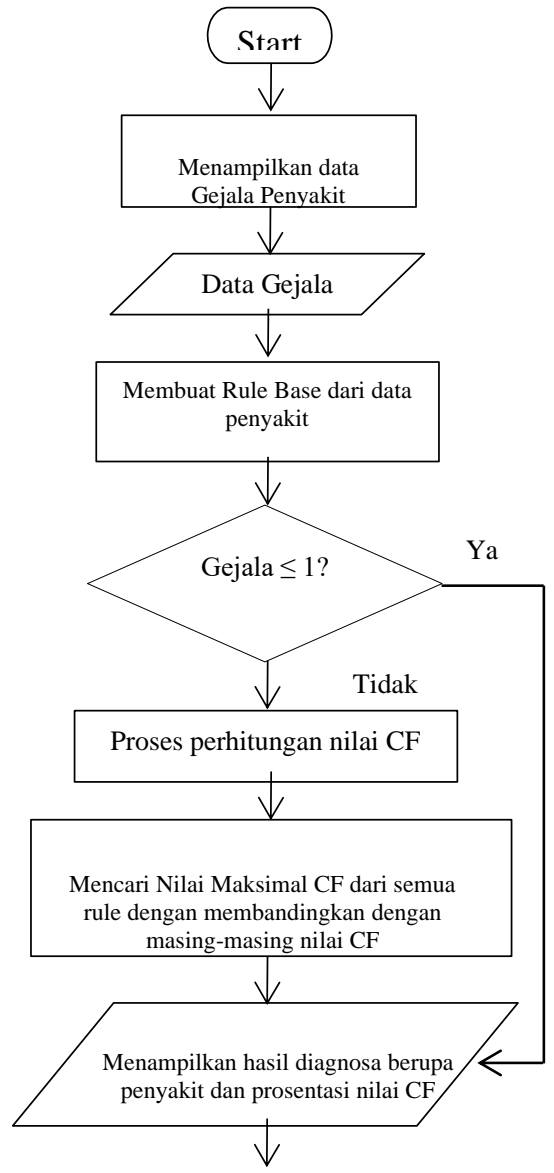

End

Gambar 3 Flowchart sistem dengan sistem pakar Certainty Factor

\subsection{Metode runut maju (forward chaining)}

Daftar tabel 5 dibawah ini adalah dasar untuk membuat aturan pada runut maju.

$\mathrm{IF}=\mathrm{A} 1(\mathrm{CF}=0,8)$ and $\mathrm{A} 2(\mathrm{CF}=06)$ and $\mathrm{A} 3(\mathrm{CF}=04)$ and $\mathrm{A} 4(\mathrm{CF}=0,4)$ and $\mathrm{A} 7(\mathrm{CF}=0,4)$ and $\mathrm{A} 8(\mathrm{CF}=0,4)$ and $\mathrm{A} 9(\mathrm{CF}=0,4)$ and $\mathrm{A} 12(\mathrm{CF}=0,4) \quad$ and $\mathrm{A} 14(\mathrm{CF}=0,4)$ THEN $\mathrm{P} 2$

$\mathrm{IF}=\mathrm{A} 3(\mathrm{CF}=0,4)$ and $\mathrm{A} 5(\mathrm{CF}=0,4)$ and $\mathrm{A} 6(\mathrm{CF}=0,6)$ and $\mathrm{A} 7(\mathrm{CF}=0,4) \quad$ and $\mathrm{A} 10(\mathrm{CF}=0,4)$ and $\mathrm{A} 11(\mathrm{CF}=0,6) \quad \mathrm{A} 14(\mathrm{CF}=0,4) \quad$ and $\mathrm{A} 15(\mathrm{CF}=0,4)$ THEN P1.

Tabel 7. Rule Diagnosa Penyakit Ginjal

\begin{tabular}{|c|c|c|c|}
\hline Kode & Gejala Penyakit Ginjal & $\begin{array}{l}\text { Ginjal } \\
\text { Kronis }\end{array}$ & $\begin{array}{l}\text { Ginjal } \\
\text { Akut }\end{array}$ \\
\hline A1 & Mual & $\checkmark$ & \\
\hline A2 & Muntah & $\checkmark$ & \\
\hline A3 & $\begin{array}{l}\text { Kehilangan selera } \\
\text { makan }\end{array}$ & $\checkmark$ & $\checkmark$ \\
\hline A4 & $\begin{array}{l}\text { Kelelahan dan } \\
\text { kelemahan }\end{array}$ & $\checkmark$ & \\
\hline A5 & $\begin{array}{l}\text { Mengalami Masalah } \\
\text { tidur }\end{array}$ & & $\checkmark$ \\
\hline A6 & Tremor Pada Tangan & & $\checkmark$ \\
\hline A7 & $\begin{array}{l}\text { Pembengkakan pada } \\
\text { kaki dan pergelangan } \\
\text { kaki }\end{array}$ & $\checkmark$ & $\checkmark$ \\
\hline A8 & $\begin{array}{l}\text { Rasa gatal yang terus } \\
\text { menerus }\end{array}$ & $\checkmark$ & \\
\hline A9 & $\begin{array}{l}\text { Sesak Napas jika } \\
\text { cairan menumpuk di } \\
\text { paru paru. }\end{array}$ & $\checkmark$ & \\
\hline A10 & Sakit Perut & & $\checkmark$ \\
\hline A11 & $\begin{array}{l}\text { Ketajaman mental } \\
\text { menurun }\end{array}$ & & $\checkmark$ \\
\hline A12 & $\begin{array}{l}\text { Otot berkendut dan } \\
\text { kram }\end{array}$ & $\checkmark$ & \\
\hline A13 & $\begin{array}{l}\text { Jarang buang air } \\
\text { kencing }\end{array}$ & & $\checkmark$ \\
\hline A14 & Pucat & $\checkmark$ & \\
\hline A15 & $\begin{array}{l}\text { Sakit pada pundak } \\
\text { dan pinggang }\end{array}$ & & $\checkmark$ \\
\hline
\end{tabular}

Nilai 0 menentukan bahwa pengguna menginformasikan bahwa user tidak mengalami gejala seperti yang ditanyakan oleh sistem. Semakin pengguna yakin bahwa gejala tersebut memang dialami oleh manusia. Proses dalam perhitungan premis majemuk dan akan menjadi kaidah-kaidah yang memiliki premis tunggal. Kemudian masing-masing aturan baru dihitung dengan Certainty Factor-nya, sehingga diperoleh dengan nilai Certainty Factor, untuk masing-masing aturan. Kemudian Certainty Factor dikombinasikan Sebagai contoh, proses pemberian bobot pada 
setiap premis (gejala) hingga diperoleh persentase keyakinan untuk penyakit Ginjal.

Langkah pertama, pakar menentukan nilai CF untuk masing-masing gejala sebagai berikut:

CFpakar $($ Mual $)=0.8$

CFpakar $($ Muntah $)=0.6$

CFpakar (Kehilangan selera makan $)=0.4$

CFpakar (Pembengkakan pada kaki $)=0.4$

CFpakar $($ Rasa gatal $)=0.4$

CFpakar $($ Sesak Napas $)=0.4$

CFpakar $($ Kram $)=0.4$

CFpakar $($ Pucat $)=0.4$

Selanjutnya dilakukan dengan penentuan bobot user, misalkan user mempunyai jawaban sebagai berikut:

Rule 1 : IF Mual = Yakin =0.8 AND Muntah = Cukup Yakin $=0.6$ AND Kehilangan selera makan $=$ Sedikit Yakin $=0.4$ AND Pembengkakan pada kaki $=$ Sedikit Yakin $=0.4$ AND Rasa gatal $=$ Sedikit Yakin $=0.4$ AND Sesak Napas $=$ Sedikit Yakin $=0.4$ AND Kram $=$ Sedikit Yakin $=0.4$ AND Pucat $=$ Sedikit Yakin $=0.4$ THEN P2 .

Rule 2 : IF Kehilangan selera makan =Sedikit Yakin=0,4 AND Mengalami Masalah tidur= Sedikit Yakin=0,4 AND Tremor Pada Tangan= Cukup Yakin $=0.6$ AND Pembengkakan pada kaki= Sedikit Yakin=0,4 AND Sakit Perut= Sedikit Yakin $=0.4$ AND Ketajaman mental menurun= Cukup Yakin $=0.6$ AND Pucat $=$ Sedikit Yakin $=0.4$ AND Sakit pada pundak dan pinggang $=$ Sedikit Yakin $=$ 0.4 THEN P1.

\subsection{Perancangan Database}

1. Perancangan database penyakit Ginjal

Database penyakit berfungsi sebagai media penyimpanan bagi jenis penyakit dan solusinya.

Tabel 7 Struktur tabel penyakit

\begin{tabular}{|l|l|l|}
\hline Field Name & Data Type & Field Size \\
\hline id_penyakit & Int & 5 \\
\hline Penyakit & Varchar & 40 \\
\hline Solusi & Longtext & - \\
\hline
\end{tabular}

2. Perancangan database gejala Penyakit Ginjal

Database gejala berfungsi menyimpan semua gejala gejala penyakit.

Tabel 8 Struktur tabel gejala

\begin{tabular}{|l|l|l|}
\hline Field Name & Data Type & Field Size \\
\hline id_gejala & Int & 5 \\
\hline Gejala & Varchar & 100 \\
\hline
\end{tabular}

3. Perancangan database buku tamu

Database komentar berfungsi menyimpan semua komentar.
Tabel 9 Struktur tabel buku tamu

\begin{tabular}{|l|l|l|}
\hline Field Name & Data Type & Field Size \\
\hline nama & Varchar & 50 \\
\hline komentar & Longtext & - \\
\hline waktu & Timestamp & - \\
\hline
\end{tabular}

2.5. Perancangan Menu Aplikasi Sistem Pakar Penyakit Ginjal

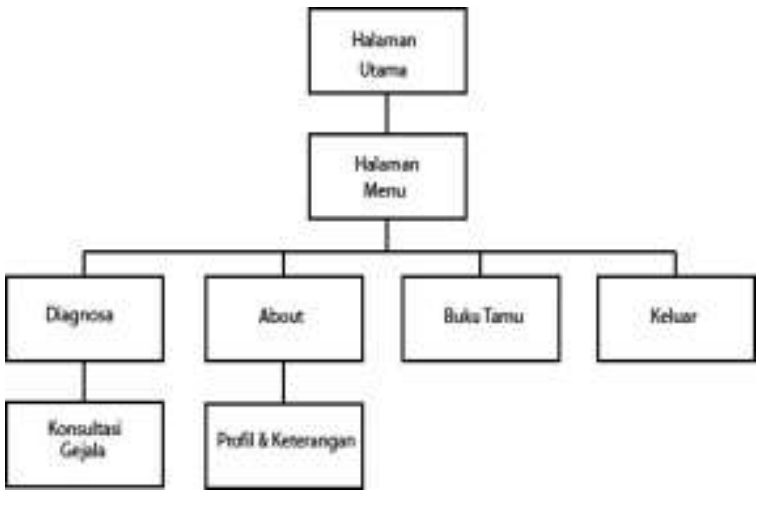

\section{KESIMPULAN}

Dalam proses membangun sistem pakar diagnosa penyakit ginjal menggunakan sistem pakar Certainty Factor ini terdapat beberapa hal yang dapat disimpulkan oleh penulis sebagai hasil evaluasi pengembangan sistem. Kesimpulan adalah sebagai berikut.

1. Sistem Pakar ini mengimplementasikan Certainty factor dengan baik ke dalam sistem pakar diagnosa ginjal.

2. Aplikasi sistem pakar diagnosa penyakit ginjal dapat melakukan diagnosa sebuah penyakit dan dapat memberikan informasi berupa definisi penyakit, pencegahan dan juga rujukan bagi pasien penyakit ginjal.

3. Sistem pakar ini dapat dijadikan alternatif bagi pasien dalam mengenali dini melalui gejala-gejala yang dirasakan.

\section{PUSTAKA}

Azhar, S. d. (2014). Sistem Pakar Penyakit Ginjal Pada Manusia Menggunakan Metode Forward Chaining. Jurnal Media Infotama Vol. 10 No. 1, 16-26.

Desaini, d. (2005). Konsep Kecerdasan Buatan. Yogyakarta: Penerbit Andi.

Efrida Warganegara, N. N. (2016). Faktor Risiko Perilaku Penyakit Tidak Menular. Majority Volume 5 Nomor 2 April 2016, 88-94.

Iri Kuswadi, d. (2020). From Textbook To Digital Medicine Era. Yogyakarta: Perhimpunan Nefrologi Indonesia.

Kesehatan, K. (2017). Pencegahan dan Pengendalian Penyakit Tidak Menulat. 
Jakarta: Direktorat Jendral Pencegahan dan Pengendalian Penyakit Tidak Menulat Kemenkes.

Kusrini. (2006). Sistem Pakar \& Pengembangannya. . Yogyakarta : Penerbit Andi.

Riadi, A. (2017). Penerapan Metode Certainty Factor Untuk Sistem Pakar Diagnosa Penyakit Diabetes Melitus Pada Rsud Bumi Panua Kabupaten Pohuwato. ILKOM Jurnal Ilmiah Volume 9 Nomor, ISSN online 2548-7779, 309-316.

Sestri novia rizki, F. L. (2017). Sistem Pakar Untuk Mendeteksi Kesalahan Elektroda Pada Proses Welding Frame Thermostat Pada Soulplate Menggunakan Metodeforward Chaining Berbasis Web. Jurnal Edik Informatika, E-ISSN : 2541-3716, 211225.

Tjekyan, R. S. (2012). Prevalensi dan Faktor Risiko Penyakit Ginjal Kronik di RSUP Dr. Mohammad Hoesin Palembang Tahun 2012. Bagian Ilmu Kesehatan Masyarakat. 